Captain K. R. Hudson for their helpful advice, and the Director General of Medical Services, Royal Air Force, for permission to publish.

\section{REFERENCES}

Bell, E. J., and Grist, N. R. (1967). Brit. med. f., 4, 741. Busby, D.' W. G., House, W., and MacDonald, J. R. (1964). Virological Davis, D. C., and Melnick, J. L. (1958). \%. Lab. clin. Med., 51, 97 Eichenwald, H. F., Abatio, A., Arky, A. M., and Hartman, A. P. (1958). 3. Amer. med. Ass., 166, 1563.

Hart, E. W., Brunton, G. B., Taylor, C. E. D., Maurice-Williams, F. E., and Coetzee, E F C. (1962). Lancet, 2, 402. and Coetze, E F C. (1962). Lancet, 2, 402.
Karzon, D. T., Eckert, G. L., Barron, A. L., Hayner, N. S., and
Winkelstein, W. (1961). Amer. F. Dis. Child., 101, 610.
Karzon, D. T., Hayner, N. S., Winkelstein, W., and Barron, A. L. (1962). Paediatrics, 29, 418.

Kibrick, S. (1964). Progress in Medical Virology, edited by J. L. Melnick, vol. 6. Basle and New York.

Landsman, J. B., and Bell, E. J. (1962). Brit. med. F., 1, 12.

Lee, L. H., Phillips, C. A., South, M. A., Melnick, J. L., and Yow, M. D '(1965). Bull. Wild Hlth Org., 32, 657.

Lenette, E. H., and Schmidt, N. J. (1964). Diagnostic Procedures for Viral and Rickettsial Diseases, 3rd ed. New York.

Lepine, P., Samaille, J., Maurin, J., Dubois, O., and Carre, M. C. (1960). Ann. Inst. Pasteur, 99, 161 .

Melnick, J. L. (1965). In Viral and Rickettsial Infections of Man, edited by F. I. Horsfall and I. Tamm, 4th ed., p. 536. London.

Ramos-Alvarez, M., and Sabin, A. B. (1958). F. Amer. med. Ass., 167,

Sabin, A. B., Krumbiegel, E. R., and Wigand, R. (1958). Amer. 7. Dis. Child., 96, 197.

Selwyn, S., and Howitt, L. F. (1962). Lancet, 2, 548.

Sommervilie, R. G. (1958). Lancet, 2, 1347.

\title{
Fatal Case of Gas Gangrene Associated with Intramuscular Injections
}

\author{
P. W. HARVEY,* V.R.D., M.B., CH.B., F.C.PATH., D.PATH. ; G. V. PURNELL, $\dagger$ M.B., CH.B.
}

Brit. med. F., 1968, 1, 744-746

This paper reports a case of fatal gas gangrene complicating a simple therapeutic injection of adrenaline mucate given in a hospital ward.

Touraine and Gautier (1936) went to considerable lengths to conceal the identity of their patient in a case similar to the one which we are reporting, and in all probability the fear of litigation has inhibited the publication of other reports. In fact, the description of this case has been delayed because a colleague originally vetoed publication. It should be emphasized that this patient died some years ago, in another place, and was in no way connected with the towns where either of us now practise.

The development of central sterile supply departments and the more recent introduction of disposable sterilized equipment have greatly reduced, but by no mean eliminated, the risk of infection, which can be introduced by injections (Cayton and Morris, 1966).

It is highly probable that the present patient would still have died even though the syringes and needles used to treat him had been prepared in accordance with the techniques employed now, many years after the tragedy.

\section{Case Report}

A 22-year-old man was admitted to hospital with severe status asthmaticus. During the first 18 hours treatment consisted of intravenous injections of aminophylline followed by intramuscular aminophylline, Hyperduric adrenaline, and Gardenal sodium (phenobarbitone sodium).

On the morning of the second day he was very much better, though he complained of some pain in the lower lumbar region and both buttocks. The consultant physician in charge of the case examined the patient, paying special attention to the buttocks, which had been the site of some of the intramuscular injections. He found no evidence of an inflammatory reaction or of focal tenderness. The patient's improvement was maintained throughout that day and evening, though he still complained intermittently of low back pain.

Early on the morning of the third day he became very restless and appeared to be ill. He was found to have acute peripheral circulatory failure, the blood pressure being unrecordable. There

- Consultant Pathologist, Royal Lancaster Infirmary.

+ Industrial Medical Officer, British Aircraft Corporation Limited, Preston. was a diffuse swelling over the right buttock and the lateral aspect of the upper third of the right thigh. Palpation of this swelling revealed obvious crepitus. Gas gangrene infection was diagnosed and the appropriate treatment instituted at 08.30 hours. This included intravenous anti-gas-gangrene serum, penicillin, and noradrenaline transfusions. Initially $1,000,000$ units of penicillin was given intramuscularly and 500,000 units intravenously.

One hour later the patient showed no evidence of response, so $200 \mathrm{mg}$. of hydrocortisone and a further 500,000 units of penicillin were added to a glucose drip. In spite of these measures he died at 12.30 hours-that is, four hours later. In retrospect, it is important to note that he had been incontinent of faeces on admission to the ward.

Necropsy was performed by Dr. G. B. Manning (Home Office pathologist) in our presence. The findings were of a classical gasgangrene infection which appeared to have arisen from a needle track 2 in. $(5 \mathrm{~cm}$.) long in the muscle of the right buttock. Subsequent histology confirmed the necropsy findings and also revealed a generalized septicaemia due to Gram-positive bacilli.

Gram-positive bacilli were cultured from the needle track and from subcutaneous tissue in the lumbar region as well as from the patient's faeces. The colonial appearances, the cultural characteristics, and the sugar and Nagler reactions of all three strains were identical and typical of Clostridium welchii.

The cultures were sent to the Central Serological Laboratory, London, for further investigation. The toxins produced by the three strains were identical and consisted of alpha, theta, and kappa toxins. The strains were therefore $\mathrm{Cl}$. welchii type $\mathrm{A}$.

Universal containers of Robertson's meat medium containing pure cultures of the organism were left on the bench for some months at room temperature. When the cultures were re-examined special stains confirmed that spores had formed. In due course sterile filter paper was impregnated with these spores and used for heatresistance tests.

\section{Literature}

The dangers of gas gangrene occurring in operating-theatres is generally recognized (Brit. med. Y., 1967), but it is less widely known that this infection can arise at the sites of intramuscular injections.

Mabin (1936) lists 84 cases, none of them in the English literature. The majority were reported from Germany and Italy and there were 10 cases from France. Further cases have since been published in the French literature by Touraine and Gautier (1936), Lagrot (1938), Brocard (1940), and Ramond 
(1942). We have found only three reports in the British literature (Harris, 1937 ; Cooper, 1946 ; Tonge, 1957).

Ramond (1942) pointed out the fulminating course followed by cases due to injection, and stated that death usually took place within 48 hours. This was certainly so in the case which we are reporting. Lagrot (1938) stated that the statistics showed a $94 \%$ mortality. Mabin (1936), reviewing 84 cases, pointed out that one-third of these were associated with injections of adrenaline, and that more cases of gas gangrene were associated with the injection of this drug than with any other. According to Mabin, in only 11 of the 84 cases which he had collected was an organism identified, and in each case it was $\mathrm{Cl}$. welchii. In all subsequent reports which we have studied, where an organism has been identified it has been $\mathrm{Cl}$. welchii.

Experimental work by Cooper (1946) and by Evans, Miles, and Niven (1948) has shown that adrenaline, administered intramuscularly, enormously enhances the danger of infection by Cl. welchii.

Pallasse (1936), Touraine and Gautier (1936), Lagrot (1938), and Ramond (1942) think that the $\mathrm{Cl}$. welchii are of endogenous origin, the organisms being present at the site of injection as the result of a transient symptomless bacteraemia originating from the bowel. There is, however, no evidence that such a bacteraemia occurs, and both Brocard (1940) and Cooper (1946) reject this theory.

In the case reported by Cooper the needle and syringe were kept in spirit, and as it is known that $\mathrm{Cl}$. welchii spores can survive in $96 \%$ alcohol she thought that the syringes and needles were the most likely source of the infection. The syringe used for the fatal injections of adrenaline in oil in the case reported by Tonge (1957) was kept in a solution of Dettol in $70 \%$ alcohol in a special container, and boiled once a week, though the needles, which were carried in a screw-capped container, were boiled daily.

\section{Discussion}

In our case the syringe and needles were boiled for at least five minutes just before each injection. Filter-paper impregnated with spores cultured from the needle track germinated after two minutes' boiling, but there was no growth after three minutes at $100^{\circ} \mathrm{C}$. It was therefore thought that the normal procedure then employed for sterilizing syringes and needles in the ward had been adequate. Though this form of sterilizing by boiling is not now acceptable (M.R.C., 1962) it was the usual practice in hospitals at the time when this death occurred.

Tests were carried out in the wards very soon after the tragedy, but no aerobic or anaerobic growth was obtained at any time from the syringes or needles found there.

All the materials injected were prepared by well-known pharmaceutical manufacturers, and it is most unlikely that the infection originated from these sources. The only material remaining for bacteriological examination was a rubber-capped stock bottle of procaine and phials of Cardophylin (theophyllineethylenediamine) and of Hyperduric adrenaline in the cartons from which phials had been taken for injection into the deceased. The contents and external surfaces of all these glass containers were cultured for $\mathrm{Cl}$. welchii, but none grew.

The possibility that the infection originated from $\mathrm{Cl}$. welchii spores contaminating the skin cannot be easily dismissed. It is known that these spores are often found on the skin of the buttocks and thighs when they are present in the faeces, and no practical method of cleansing will destroy them (Garrod, 1956 ; M.R.C., 1962). The fact that the cultures from the patient's wound and faeces were similar supported the hypothesis that the infection was due to inoculation of $\mathrm{Cl}$. welchii derived from the patient's own faeces by an injection of Hyperduric adrenaline. This hypothesis could not be confirmed or refuted, as all the strains of $\mathrm{Cl}$. welchii concerned were untypable.
Shortly after the young man died two old men in the same ward were found to have gas in the tissues at points where injections had been made into the buttocks. Cl. welchii type A was isolated from both these wounds. Neither of them showed clinical evidence of gas gangrene. In both cases the infections involved subcutaneous fat and not muscle. Both patients were debilitated and were incontinent of faeces. It is our opinion that the probable sources of infection in all three cases were spores from the patients' own faeces.

Though all injection sites were infected with $\mathrm{Cl}$. welchii type A only one person, a robust young man, died. The other two patients, both aged and feeble, appeared to suffer no serious ill effects.

The fact that the fatal case alone was associated with injections of Hyperduric adrenaline is of crucial importance. The vasoconstriction caused by adrenaline lowers the oxygen tension to a point which enables anaerobic organisms to grow. Evans et al. (1948) have shown experimentally that infection by $\mathrm{Cl}$. welchii, in particular, is greatly enhanced by the presence of adrenaline at the site of injection. They concluded that the injection of $2 \mu \mathrm{g}$. of adrenaline into the thigh muscles of guinea-pigs enhanced such infection at that site 100,000 times. In their experiments a simple solution of adrenaline was used. In the case reported here at least $500 \mu \mathrm{g}$. of adrenaline was injected, combined with mucic acid.

This association of Hyperduric adrenaline with $\mathrm{Cl}$. welchii bacilli is thought to have been responsible for the fulminating course of this infection and for the fatal outcome of the case.

Hyperduric adrenaline is the trade name for adrenaline mucate. It is thought that this form of adrenaline has been produced by one firm only. It has recently been withdrawn by the manufacturers for economic reasons, together with the other Hyperduric preparations. It consists of adrenaline $0.1 \%$, mucic acid $0.2 \%, \mathrm{NaCl} 0.9 \%$, phenyl mercuric nitrate $0.002 \%$, sodium metabisulphite $0.15 \%$ and aqua pro inject. ad $100 \%$. Its prolonged action is due to hydrolysis of adrenaline mucate within the tissues to release pharmacologically active adrenaline. Equal volumes of adrenaline injection B.P. (1:1000) and of Hyperduric adrenaline contain equal quantities of adrenaline. That contained in the mucate is released slowly; activity may be detected in 30 minutes and continue for as long as eight or even 12 hours.

The effect of $\mathrm{Cl}$. welchii and its exotoxins on adrenaline mucate is not known.

\section{Conclusions}

$\mathrm{Cl}$. welchii are ubiquitous and easily cultured from dust.

These organisms must often contaminate sterilized syringes and instruments, yet reports of their causing trouble are few. Cl. welchii are frequently cultured from wounds in which they appear to be of little importance and certainly do not cause gas gangrene.

Whatever the source of the bacteria, it was the presence of adrenaline in the tissues which exacerbated the infection and brought about the death of the patient. In the other two cases the infection, also in the buttocks, had no significant effect on the clinical progress.

The possible presence at the site of an intramuscular injection of spores on the skin is a hazard which still cannot be eliminated. It is therefore our practice to avoid injections of adrenaline into the buttock whenever possible.

\section{Summary}

A fatal case of gas gangrene is reported. It followed a therapeutic injection of adrenaline mucate in a hospital ward, and is thought to have been due to spores derived from the 
patient's own faeces which contaminated the skin and were driven into the muscle by the injection needle. They germinated in the favourable environment induced by the adrenaline.

There is no adequate way of sterilizing the skin to prevent such tragedies, so adrenaline injections should not be made into the buttock.

The literature, mainly from Europe, is reviewed.

We should like to record our appreciation of the assistance given to us by the late Colonel $\mathrm{H}$. J. Benstead of the Central Laboratory at Colindale, London. We are also grateful to Professor C. L. Oakley, F.R.S., for his advice and comments, to Mr. J. D. Bellis for assistance with pharmacological data, and to Miss Sylvia Curwen for typing.
REFERENCES

Brit. med. F., 1967, 4, 68

Brocard, H." (1940). C.R. Soc. Biol. (Paris), 134, 567

Cayton, H. R., and Morris, C. A. (1966). Mth Bull. Minist. Hlth Lab. Serv., 25, 87.

Cooper, E. V. (1946). Lancet, 1, 459.

Evans, D. G., Miles, A. A., and Niven, J. S. F. (1948). Brit. F. exp. Path. 29. 20.

Garrod, L. P. (1956). Brit. med. 7., 2, 415.

Harris, D. P. (1937). Brit. 1. Anoesth. 14, 130

Lagrot, F. (1938). Presse méd., 46, 1657.

Mabin, $G$. (1936). La Gangrène Gaxeuse après Injections Médicamen-

M.R.C. (1962). Memorandum No. 41, The Sterilization, Use, and Care of Syringes, p. 9. London.

Pallasse, E. (1936). Lyon méd. 158, 249.

Pallasse, E. (1936.). Lyon med. 158, 249. Paris, 58, 421.

Ramond, L. (1942). Bull. Soc. méd. Hop.

Touraine, A., and Gautier, j. (1936). Bull. Soc. franc. Derm. Syph., 43, 778.

\section{Preliminary Communications}

\section{Release of Platelet Factor 4 by Adenosine Diphosphate and other Platelet- aggregating Agents}

\section{Brit. med. F., 1968, 1, 746-747}

Relatively little is known about the availability and physiological significance of platelet factor 4 , the antiheparin principle in platelets. Platelet factor 4 may be a polypeptide or glycoprotein of low molecular weight (Deutsch and Kain, 1961; Poplawski and Niewiarowski, 1964). It seemed possible that, like platelet factor 3 , the platelet thromboplastic factor, it was not immediately available in intact platelets and that release of activity might be induced by platelet-aggregating agents such as adenosine diphosphate, collagen, thrombin, adrenaline, and 5hydroxytryptamine, all of which are known to activate platelet factor 3.

We have been investigating the antiheparin activity of human platelets, and in this communication we report our observations with platelet-aggregating agents which we have found to release platelet factor 4 from platelets.

\section{MATERIALS AND METHODS}

Collection of Blood.-Blood was obtained from normal human subjects by careful venepuncture and gently mixed with $1 / 10$ volume of $3.8 \%$ trisodium citrate in a plastic bottle.

Platelet-rich Plasma.-The citrated blood was slowly centrifuged at room temperature to obtain plasma rich in platelets but containing negligible numbers of red cells or white cells. After removing the supernatant platelet-rich plasma, which was transferred to a clean plastic bottle, the remaining blood was centrifuged at high speed to obtain plasma poor in platelets.

Thrombin (Maws) was dissolved in a mixture of equal volumes of normal saline and $M / 80$ calcium to give the required thrombin concentration.

Heparin (Weddel).-The working solution was made up in normal saline from a stock solution of $10 \mathrm{mg} . / \mathrm{ml}$.

Aggregating Agents.-All were dissolved in normal saline, and the concentration was such that $0.1 \mathrm{ml}$. contained the following amount of aggregating agent:adenosine diphosphate $(5 \mu \mathrm{g}$.$) , adrenaline (100 \mu \mathrm{g}$.$) , or 5-hydroxytryptamine (500$ $\mu \mathrm{g}$.). Collagen obtained from bovine tendon was macerated in normal saline; the milky supernatant obtained after allowing the large fragments to settle out of solution was used. Thrombin used in the aggregating experiments was added in amounts which did not clot plasma (0.09 unit $/ 0.1 \mathrm{ml}$.).

Detection of Platelet Factor 4 Activity.-The test system was made up as follows: $0.2 \mathrm{ml}$. of platelet-rich plasma was incubated with $0.1 \mathrm{ml}$. heparin $(1 \mu \mathrm{g}$.) and $0.1 \mathrm{ml}$. of test material or saline for two minutes at $37^{\circ} \mathrm{C}$. with gentle agitation. Then $0.1 \mathrm{ml}$. of thrombin ( 1.5 units) was added and the plasma clotting-time was determined.

\section{RESULTS}

Availability of Platelet Factor 4.-It was found that the antiheparin activity of platelet-rich plasma (carefully collected and handled) was little different from that of platelet-poor plasmathat is, the prolongation of the plasma clotting-time produced by a standard amount of heparin was about the same. However, breaking up the platelets by freezing and thawing the platelet-rich plasma produced obvious antiheparin activity (see Table). The changes in platelet-poor plasma were relatively insignificant after freezing and thawing, and it is therefore reasonable to assume that the platelets were responsible for this antiheparin effect. Effect of Freezing and Thawing and of Platelet-aggregating Agents on
Antiheparin Activity of Normal Human Platelet-rich Plasma

\begin{tabular}{|c|c|c|}
\hline Test System & & $\begin{array}{l}\text { Thrombin } \\
\text { Time } \\
\text { (sec.) }\end{array}$ \\
\hline 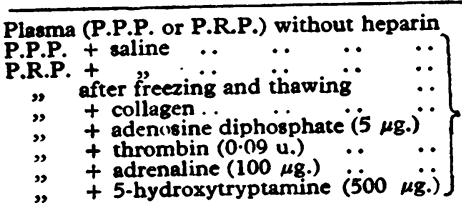 & 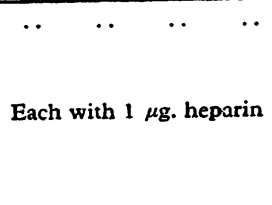 & $\begin{array}{l}12-13 \\
35 \\
34 \\
17 \\
16 \\
19 \\
21 \\
24 \\
23\end{array}$ \\
\hline
\end{tabular}

Effect of Platelet-aggregating Agents.-It will be seen from the Table that all the agents used made available or released antiheparin activity, adenosine diphosphate and collagen being the most potent. After removal of the platelets by fast centrifugation much of the released platelet factor 4 activity seemed to remain in the supernatant. 